\title{
Feasibility Analysis on the Business Plan of Herb Medicines at Ginsanjaya Pharmacy
}

\author{
Gunawan Yohanda $^{1}$, Rizal Syarief ${ }^{2}$, Yidha Herywan Asnawi ${ }^{3}$ \\ ${ }^{1,2,3}$ Graduate IPB Business School, Indonesia. \\ Corresponding Author: Gunawan Yohanda
}

DOI: https://doi.org/10.52403/ijrr.20220163

\begin{abstract}
The objectives of this study are analysis about feasibility on the business plan of herb medicines at Ginsanjaya Pharmacy, which are: feasibility analysis of industry and market, feasibility analysis of products and services, feasibility analysis of financial; and to decide the business plan of herb medicines at Ginsanjaya Pharmacy is feasible or not feasible to be realized or operated. The study methodologies used are: (1) The feasibility analysis of industry and market such as: market and marketing aspects, industrial environment aspects, economical - social - legal environmental aspects, by qualitative desciptive analysis. (2) The feasibility analysis of products and services such as: technical and technological aspects, operational management aspects, human resources aspects, by qualitative descriptive analysis. (3) The feasibility analysis of financial aspects such as: payback period, present value, internal rate of return, profitability index, break even point, by quantitative descriptive analysis. The results of feasibility analysis on the business plan of herb medicines at Ginsanjaya Pharmacy were such as: (1) The feasibility analysis of industry and market such as : market and marketing aspects were feasible, industrial environment aspects were feasible, economical - social - legal environmental aspects were feasible, therefore the industrial and market aspects were feasible. (2) The feasibility analysis of products and services such as: technical and technological aspects were feasible, operational management aspects were feasible, human resources aspects were feasible, therefore the products and services aspects were feasible. (3) The feasibility analysis of financial aspects such as :
\end{abstract}

payback period 3.49 years < project period 5 years ; net present value $\operatorname{Rp} 329,019,000>0$ (positive) ; internal rate of return $27.17 \%>$ bank credit rate $5.58 \%$; profitability index 2.04 $>1$; break even point of 5 th year $\mathrm{Rp}$ $718,743,000$ or $28.94 \%$; therefore the financial aspects were feasible. Therefore the final conclusion of study was that feasibility analysis on the business plan of herb medicines at Ginsanjaya Pharmacy was passed, was feasible to be realized and operated.

Keywords: break even point, feasibility analysis, internal rate of return, net present value, payback period, profitability index.

\section{INTRODUCTION}

Consumer behavior has changed, global issue "back to the nature"(back to nature), consumers are starting to lead to health (healthy) and wellness (fit). People are beginning to realize the benefits of healthy living behaviors, impacting the positive growth of herbal business lines. People began to switch to using natural ingredient drugs to minimize the side effects of pharmaceutical chemical drugs.

Natural medicinal ingredients (herbal, traditional) have been widely accepted in poor, middle, to developed countries. Indonesia is very rich with various species of flora, the 2nd largest biodiversity in the world after Brazil. As many as 40,000 types of flora that grow in the world, 30,000 species grow in Indonesia, 9,600 types of medicinal plants. About 26\% have been cultivated and the remaining $74 \%$ still grow wild in the forest, 
Indonesia is known as a warehouse of medicinal plants (herbs), so it is nicknamed "live laboratory". Medicinal plants that have been used as raw materials for new herbal medicine 500 types, herbal products registered in BPOM (Food and Drug Administration) there are 11,000, new standard herbal medicine 98 products, new phytoarmaka drugs 36 products. Indonesia has owned / enacted the Indonesian Herbal Pharmacopoeia Edition II 2017, Formulary Herbal Medicine Indonesia (FROTI) 2017, Guidelines on How to Make Good Traditional Medicine (CPOTB). Indonesia is still lagging behind in the use of natural ingredients (herbal) drugs compared to China, Japan, South Korea, India, Vietnam. (Balitbang Depkes, 2009; Hernani, 2011; I Fidrianny, 2017; B Elya, 2018; PK Lukito and R Indriani, 2021).

Since the outbreak of the Covid 19 pandemic almost two years ago the consumption of herbal medicines increased, herbal and organic products began to become a healthy lifestyle. The business of herbal medicine and registration of herbal medicines to BPOM is increasing. Large pharmaceutical factories such as Kalbe Farma and Dexa Medica began to develop and produce herbal remedies. The largest herbal medicine factory, Sido Muncul, posted sales in 2020 of $\mathrm{Rp} 3.335$ trillion, sales rose $9 \%$, operating profit rp 1.15 trillion, net profit rp 934 billion. (PK Lukito, 2021; D Hidayat, 2021).

Entrepreneurs plan a business / herbal medicine business at Ginsanjaya Pharmacy in Kranggan Permai Blok S6 Number 5 Jati Sa mpurna, Cibubur Raya, Bekasi City. Pharmacies provide health and pharmaceutical services, general practitioner practice services, simple clinical laboratories, distribution of pharmaceutical supplies: prescription hard drugs, mandatory pharmacy hard drugs (without prescriptions), over-the-counter medicines, herbal medicines and supplements (majority/dominant percentage), medical devices and personal protective equipment, baby products, cosmetics and beauty tools, sanitation and hygiene, water purifiers; comprehensive pharmaceutical services to improve the quality of life of patients (pharmaceutical care), clinical pharmacy, drug information, drug monitors.

Herbal medicine start-ups in pharmacies require business planning and business plan feasibility analysis. A business plan is the process of determining whether an entrepreneur's business idea is the foundation that can survive, worthy of forming a successful business. If the business idea passes the entrepreneur proceeds by building a solid business plan. (TW Zimmerer \& NM Scarborough, 2008).

The purpose of the study is as follows: (a) Conduct a feasibility analysis of the drug business plan at Ginsanjaya Pharmacy: industrial feasibility analysis and pasar, product or service feasibility analysis, financial feasibility analysis (financial). (b) Decide whether the herbal medicine business in Ginsanjaya Pharmacy is feasible or not worth being realized/operated.

\section{METHODS}

The object of the study is Ginsanjaya Pharmacy, located in Kranggan Permai Blok S6 No. 5 Jatisampurna / Cibubur, Bekasi City; with pharmaceutical supplies the majority / dominant percentage is herbal medicine. Ginsanjaya Pharmacy is still in the realm of planning /project, has not been realized. Research time: February to July 2021.

Sampling techniques in research are purposive sampling, intentionally selecting a particular person, entrepreneur or experienced manager from a pharmacy or supplier company. Data collection techniques include: (a) Primary data collection is through direct observation or field surveys, questionnaires, in-depth interviews with experienced entrepreneurs or managers from pharmacies or suppliers of prescription pharmaceutical chemical drugs and over-the-counter drugs, herbal and spice medicines, cosmetics, medical devices, water purifier tools and chemicals, 
baby products. The interview is guided by a list of questions (questionnaires) or checklists (check list) that have been compiled in advance. Survey or interview in Jakarta, Bogor, Tangerang, Bekasi, Bandung, Yogyakarta. (b) Secondary data collection is through literature studies, scientific books, journals, articles, data from the Central Bureau of Statistics, previous research reports (thesis, thesis, dissertation), internet, pharmacy operational books/ documents, company/pharmacy annual reports, bench marking (comparative studies), economic factor projections, subdistrict office data.

Data processing/analysis techniques carried out in the research are:

(a) Analysis of industry and market feasibility: descriptive qualitative analysis of market and marketing aspects, aspects of the industrial environment, political aspects - economic - social - legal environmental. (b) Analysis of the feasibility of products and services: descriptive qualitative analysis of technical and technological aspects, aspects of operations management, aspects of human resources. (c) Financial feasibility analysis: descriptive quantitative analysis PP (payment period), NPV (net present value), IRR (internal rate of return), PI (profitability index), BEP (breakeven point). (TW Zimmerer \& NM Scarborough, 2008; H Umar, 2007).

Data on key factors of market and marketing aspects, aspects of the industrial environment, political aspects - economic social - legal - environmental, aspects of engineering and technology, aspects of operations management, aspects of human resources each conducted descriptive qualitative analysis, measured by likert scale method. The Likert scale is a psychometric scale that can be used to measure the attitudes, opinions, perceptions of a person or group of people about social symptoms or phenomena, society, education, subjective/abstract, requiring many indicators, dimensions, variables, constructed/ operationally defined in order to be objective, measurable, easy to do; Originally a bipolar scale to measure a person's agreed and disapproval of an object, a positive or negatip response to a statement as a research variable. Each key factor is rated 1 to 5 , the weight of each key factor is considered the same, because it is still in the project/plan period, not yet the realization of the operation. Value $1=$ very bad, very unimportant, very disapproving, dissatisfied; 2 = bad, unimportant, disagreed, less satisfied; 3 = good enough, important enough, hesitant/neutral, quite satisfied; 4 = good, important, agree, satisfied; $5=$ very good, very important, very agreeable, very satisfied. The total aspect value is averaged, the value of the > aspect 3.00 means it is worth the aspect. (U Sumarwan et al, 2018; Sugiyono, 2008).

Payback period (PP, repayment period) is the period of time required to recoup investment expenses (initial cash investment) using cashflow, is the ratio of unit time between initial cash investment and its cash inflow. If the payback period is shorter than the projected projected time frame, then the investment proposal is acceptable. (H Umar, 2007; S Sutojo, 1993).

Internal rate of return (IRR, internal interest rate) is the interest rate that when used to discount the entire difference in cash in the years of operation of the project will generate a cash amount equal to the amount of project investment. If the IRR earned is greater than the bank's interest rate, then the investment is acceptable. (H Umar, 2007; S Sutojo, 1993).

Net present value (NPV, the net value of the project now) is obtained by discounting the difference between the amount of cash out of project funds and the cash in the project fund each year, with one percentage rate of interest that has been previously established. If the NPV $>0$ then the project proposal is accepted; if NPV $=0$ then the company value remains, the project proposal is accepted or rejected; if the NPV $<0$ then the project proposal is rejected. $(\mathrm{H}$ Umar, 2007; S Sutojo, 1993). 
Profitability index (PI, profitability index) is a comparison index between the present value of future netcash receipts plans and the present value of investments that have been implemented; or the comparison between the present value of cash in and the present value of outgoing cash. If the PI $>1$ then the project proposal is profitable and accepted; if the PI $<1$ then the project proposal is detrimental and rejected. (H Umar, 2007; S Sutojo, 1993).

Break even point (BEP, capital turning point, breakeven point) is the point when the amount of product sales in a given period equals the amount of costs borne, so that the business project is right not to lose money but also not profit or break even or return capital. When the results of product sales cannot exceed this break-even point, then the project does not provide profit / profit, the project proposal is rejected. The proceeds of product sales must be greater than the break-even point in order to earn a profit/profit, the project proposal is accepted. (H Umar, 2007; S Sutojo, 1993).

\section{RESULTS}

Because there is still an outbreak of pandemic disease covid 19 (corona virus desease 2019) since January 2020 until now, then the collection of data from secondary data sources through: literature studies, scientific books, journals / research articles, BPS data (Central Bureau of Statistics), previous research reports (thesis, thesis, dissertation), internet, benchmarking (comparative studies), economic factor projections, subdistrict office data, annual reports of companies / pharmacies.

Primary data collection through: live field surveys, interviews, comparative studies only verification. Survey of pharmacies / herbal medicine stores operating in Kranggan Permai, in Jati Sampurna District, in Cibubur Raya; comparative study of various pharmacies / herbal medicine stores in Jati Sampurna: Kimia Farma Kranggan Pharmacy, Farma Grand Citra Chemical Pharmacy, Farma Pondok Chemical Pharmacy
Jasmine, Watson Healthcare Plaza Cibubur; in Tangerang : Pharmacy Thanks to Modernland, Pharmacy GOR Medika, Pharmacy Tirta Mandiri, Toko Dunia Alkes Modernland; in Bandung: Toko Jamu Babah Kuya, Pharmacy Pioneer Pasar Baru Andir; observation of patient / consumer visitors per day at Kimia Farma Kranggan Permai Pharmacy, Farma Grand Citra Chemical Pharmacy.

Ginsanjaya Pharmacy is still in the form of planning / business projects, not yet realized. Qualitative and quantitative data are mainly still assumptions, predictions, or estimates with 5-year projections. Economic inflation conditions are assumed not to rise to $10 \%$, the price of USD / IDR rate does not rise $10 \%$, the purchase price of pharmaceutical supplies does not rise $10 \%$, the sales price of pharmaceutical supplies does not rise $10 \%$, the price of goods sold pharmaceutical supplies does not rise $10 \%$, the number of buyers / consumers does not fall $10 \%$.

Analysis of market aspect data and marketing of pharmacies using benchmarking methods, namely comparative studies with pharmacies that have been operating and successful in Jati Sampurna District, Cibubur Raya, Bekasi City, Kimia Farma Kranggan Permai Pharmacy. Patient/consumer visitor number of data prescription or transaction, amount of income per day, per month (30 days) at Farma Kranggan Permai Pharmacy is only an estimate based on interviews with pharmacystaff, direct observation, and Annual Report of Kimia Farma Pharmacy, due to time constraints and pandemic period Covid -19.

For Ginsanjaya Pharmacy the potential market is available in accordance with the population of Jati Sampurna District, 161,207 people. The target market

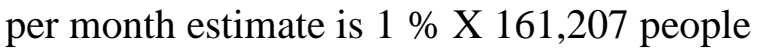
$=1,612$ people. Number of patient/consumer visitors per estimated day $=1 / 25 \times 1,612$ people $=64$ people. The face value of the recipe or transaction is

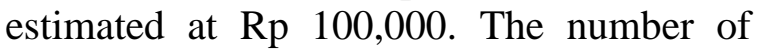


sales per day is estimated at $\mathrm{Rp} 6,400,000$, the number of sales per month estimates $\mathrm{Rp}$ $160,000,000$. The population growth of Jati Sampurna District or the potential market estimates $1 \%$ a year $=1,612$ people. Target market growth estimates $1 \%$ a year $=16$ people.

The value of the market and marketing aspects of descriptive qualitative analysis: $3.32>3.00$, worthy of the market and marketing aspects.

The value of industrial environmental aspects of descriptive qualitative analysis: $3.25>3.00$, worthy aspects of the industrial environment.

Value economic, social, legal, environmental aspects of descriptive qualitative analysis: $3.14>3.00$, worthy economic, social, legal, environmental aspects.

The value of the engineering and technological aspects of descriptive qualitative analysis: $3.71>3.00$, worthy of engineering and technological aspects.

The value of operational management aspects of descriptive qualitative analysis: $3.18>3.00$, worthy of operational management aspects.

The value of the human resources aspect of descriptive qualitative analysis: $3.46>3.00$, worthy of the human resources aspect.

The investment funds needed at the beginning of the pharmacy projection year are asset capital (assets) amounting to Rp $460,131,000$, working capital amounting to Rp 106,300,000, the total amount of modal investment of Rp566,431,000, the amount of herbal medicine investment capital of Rp $316,805,000$ (55.93), can be financed by its own capital.

Projected Cash Flow Year 0 - 5. 0th year cash balance: $(\operatorname{Rp} 12,275,000), 1$ st year cash balance: Rp 2,425,000, 2nd year cash balance : $\operatorname{Rp} 79,245,000$, and so on increased to 5th year cash balance: $\mathrm{Rp}$ $804,437,000$. Cash balance of herbal medicine year $0:(\operatorname{Rp} 6,865,000)$, cash balance year 1: Rp 818,000, cash balance year $2: \operatorname{Rp~35,676,000,~and~so~on~increased~}$ to the cash balance of the year to $5: \mathrm{Rp}$ $533,020,000$. Cash balance is always positive (>0), always increasing / growing, worthy of the financial aspect.

Projected Sales of Pharmaceutical Supplies Year 1 - 5. Total sales of pharmaceutical supplies estimated for 1 year: $\mathrm{Rp} 1,528,200,000$, total sales of pharmaceutical supplies estimated for $2: \mathrm{Rp}$ $1,949,000,000$, total sales of pharmaceutical supplies estimated year to 5: Rp 3,748,800,000. Sales of herbal medicines estimated in the year $1: \mathrm{Rp}$ $515,400,000(33.73 \%)$, sales of herbal medicines in the year 2: Rp 877,400,000 $(45.02 \%)$, herbal medicine sales estimated year to year $5: \operatorname{Rp} 2,484,000(66.26 \%)$.

$$
\text { Projected Purchase of }
$$

Pharmaceutical Supplies Year 1 - 5. Total purchase of pharmaceutical supplies estimated for 1 year: Rp 1,266,000,000, total purchase of pharmaceutical supplies estimated year to 2: Rp 1,604,280,000, total purchase of pharmaceutical supplies estimasi year5 : Rp 3,052,080,000. Purchase of herbal medicine estimated year to $0: \mathrm{Rp}$ 32.800.000, year 1: $\operatorname{Rp~412,320,000,~year~} 2$ : $\mathrm{Rp} 701,920,000$, year 5 : $\mathrm{Rp}$ 1,987,200,000.

Projected Operating Expenses Year 1 - 5. Total operating costs estimated for 1 year: $\mathrm{Rp} 208,800,000$, total operating costs estimated year to $2: \operatorname{Rp} 229,200,000$, total operating costs estimated year to 5 : Rp 313,988,000.

Projected 1st Year Earnings/Loss Statement - 5. Netyear estimate to $1: \mathrm{Rp}$ $53,400,000, \quad 2$ nd year estimated net profit: Rp 115,520,000，55,000 year estimated net profit: Rp 382,732,000. Net profit of herbal medicine estimated year 1: Rp 18,012,000, year 2 : $\mathrm{Rp} 52,007,000$, year 5 : $\mathrm{Rp}$ $253,598,000$. Laba bersih always positive (> 0 ), always increased, worthy of the financial aspect.

Break Even Point (BEP) calculation. BEP year 1:Rp $999,009,000$ or $65.37 \%$. BEP year 2:Rp $952,545,000$ or $48.87 \%$. BEP year 5:Rp $1,084,732,000$ or $28.94 \%$. BEP herbal medicine year 1: $\mathrm{Rp}$ 
$336,966,000$ or $65.37 \%$, year 2: $\mathrm{Rp}$ $428,836,000$ or $48.87 \%$, year 5: Rp718,743,000 or $28.94 \%$. The percentage of BEP (breakeven point)is gettingsmaller, total sales compared to BEP are getting bigger, worthy of the financial aspect.

Calculation of Net Present Value (NPV) and Internal Rate of Return (IRR). The NPV value of total cash flow during the 5-year projection with a discount interest of $5.58 \%(0.0558)$ is $\mathrm{Rp} 543,461,000>0$ (positip), worthy of the financial aspect. The value of NPV herbal medicine Rp $329,019,000>0$ (positip), worthy of the financial aspect. The value of the IRR for the 5-year projection is $27.412 \%>$ bank loan interest of $5.58 \%$, worthy of the financial aspect. The IRR value of $27.17 \%$ $>$ bank loan interest of $5.58 \%$, is financially viable.

Payback Period (PP) calculation. Initial investment value: $\mathrm{Rp} 566,431,000$, payback period:3.32 years (3 years 4 months) < project term of 5 years, worthy of financial aspects. Initial investment value of herbal medicine: Rp 316,805,000, return on investment period: 3.49 years (3 years 5.88 months) $<$ project term of 5 years.

Calculation of Profitability Index (PI). The present value of total operating cash inflows: Rp 1,109,892,000, the present value of investment: $\mathrm{Rp} 566,431,000$. For the projected 5-year cash flow, the value of the profitability index or benefit cost ratio (BCR) is $1.96>1$, meaning the amount of cash flow balance $>$ the value of the initial investment, worthy of the financial aspect. The present value of the total cash inflow of herbal medicine operations: $\mathrm{Rp}$ $645,824,000$, the present value of herbal medicine investment: Rp 316,805,000, the profitability index value of herbal medicine is $2.04>1$, meaning the amount of cash flow balance $>$ the initial investment value, worthy of financial aspects.

\begin{tabular}{|c|c|c|c|c|c|c|c|c|c|}
\hline No & DESCRIPTION & $\begin{array}{l}\text { IRR } \\
(\%)\end{array}$ & $\begin{array}{l}\text { COST OF } \\
\text { CAPITAL } \\
(\%)\end{array}$ & PI & $\begin{array}{l}\text { BEP } \\
(\%)\end{array}$ & $\begin{array}{l}\text { NPV } \\
\text { (RP } \\
\text { 1000) }\end{array}$ & $\begin{array}{l}\text { PP } \\
\text { (YEAR) }\end{array}$ & $\begin{array}{l}\text { ACF } \\
\text { TH 5 } \\
(\text { RP X } \\
\text { 1000) }\end{array}$ & FEASIBILITY \\
\hline 1 & Expected conditions & $\begin{array}{l}27, \\
412 \\
\end{array}$ & 5,58 & 1,96 & 28,94 & 543.461 & 3,32 & 804.437 & $\begin{array}{l}\text { Worthy of the } \\
\text { financial aspect }\end{array}$ \\
\hline 2 & $\begin{array}{l}\text { Increase in the purchase price of } \\
\text { pharmaceutical supplies by } 10 \%\end{array}$ & $<0$ & 5,58 & 0,42 & 66,74 & $(331.099)$ & $>5$ & $<0$ & $\begin{array}{l}\text { Not worthy of } \\
\text { the financial } \\
\text { aspect }\end{array}$ \\
\hline 3 & $\begin{array}{l}\text { Increase in the sales price of } \\
\text { pharmaceutical supplies 10\%, } \\
\text { resulting in a decrease in the } \\
\text { number of buyers / consumers } \\
10 \% \text {, a decrease in the total } \\
\text { volume of sales of } \\
\text { pharmaceutical supplies } 10 \%\end{array}$ & $<0$ & 5,58 & 0,075 & 95,26 & (524.115) & $>5$ & $<0$ & $\begin{array}{l}\text { Not worthy of } \\
\text { the financial } \\
\text { aspect }\end{array}$ \\
\hline 4 & $\begin{array}{l}10 \% \text { increase in operating } \\
\text { expenses }\end{array}$ & 23,15 & 5,58 & 1,764 & 32,79 & 432.747 & 3,60 & 671.285 & $\begin{array}{l}\text { Worthy of the } \\
\text { financial aspect }\end{array}$ \\
\hline 5 & $\begin{array}{l}10 \% \text { increase in the cost of goods } \\
\text { sold }\end{array}$ & $<0$ & 5,58 & 0,294 & 73,31 & (399.941) & $>5$ & $<0$ & $\begin{array}{l}\text { Not worthy of } \\
\text { the financial } \\
\text { aspect }\end{array}$ \\
\hline 6 & $\begin{array}{l}\text { Decrease in the number of buyers } \\
/ \text { consumers } 10 \% \text {, resulting in a } \\
\text { decrease in the total number of } \\
\text { sales of pharmaceutical supplies } \\
\text { and revenues of } 10 \%\end{array}$ & $<0$ & 5,58 & 0,075 & 95,26 & $(524.115)$ & $>5$ & $<0$ & $\begin{array}{l}\text { Not worthy of } \\
\text { the financial } \\
\text { aspect }\end{array}$ \\
\hline 7 & $\begin{array}{l}\text { Increase in inflation up to } 10 \% \text {, } \\
\text { resulting in an increase in the } \\
\text { purchase price of pharmaceutical } \\
\text { supplies } 10 \% \text { an increase in } \\
\text { operating costs of } 10 \% \text {, an } \\
\text { increase in the sales price of } \\
\text { pharmaceutical supplies } 10 \% \text {, a } \\
\text { decrease in the number of } \\
\text { consumers } 10 \% \text {, a decrease in the } \\
\text { total number of sales of } \\
\text { pharmaceutical supplies and } \\
\text { revenues of } 10 \% \text {. }\end{array}$ & $<0$ & 5,58 & 0,075 & 95,26 & (524.115) & $>5$ & $<0$ & $\begin{array}{l}\text { Unworthy } \\
\text { Financial } \\
\text { aspects }\end{array}$ \\
\hline
\end{tabular}




\begin{tabular}{|c|c|c|c|c|c|c|c|c|c|}
\hline \multicolumn{10}{|c|}{ Table 1 Continued... } \\
\hline 8 & $\begin{array}{l}\text { Increase in the exchange rate of } \\
\text { USD / IDR } 10 \% \text { to Rp15,730 / } \\
\text { USD, resulting in an increase in } \\
\text { the purchase price of } \\
\text { pharmaceutical supplies } 10 \% \text {, an } \\
\text { increase in operating costs of } \\
10 \% \text {, an increase in the sales } \\
\text { price of pharmaceutical supplies } \\
10 \% \text {, a decrease in the number of } \\
\text { consumers } 10 \% \text {, a decrease in the } \\
\text { total number of sales of } \\
\text { pharmaceutical supplies and } \\
\text { revenues } \\
10 \%\end{array}$ & $<0$ & 5,58 & 0,075 & 95,26 & $(524.115)$ & $>5$ & $<0$ & $\begin{array}{l}\text { Not worthy of } \\
\text { the financial } \\
\text { aspect }\end{array}$ \\
\hline
\end{tabular}

Ginsanjaya Pharmacy passed the project feasibility analysis / business plan, passed the analysis of financial aspects, passed the analysis of non-financial aspects, worthy to be realized, realized, and operated. Further research should be conducted to advance, develop, perpetuate the company/pharmacy business: analysis of $\mathrm{S} \mathrm{W} \mathrm{O} \mathrm{T}$ (strengths, weaknesses, opportunities, threats); marketing mix strategy analysis $7 \mathrm{P}$ (product, price, place, promotion, people, physical evidence, process); strategic analysis of 5 dimensions of customer satisfaction (responsiveness, assurance, tangible, emphaty, reliability); canvas business model strategy analysis (customersegments, value propositions, channels, customer relationships, revenue streams, key resources, key activities, key partnerships, cost stuctures). Pharmacy management can continue the creation of a written summary of the business plan protocol.

In addition, pharmacy management can implement / implement a quality management system (ISO 9001), although not yet certified. Pharmacy management can improve the operational performance of pharmacies by increasing the values of key factors of industrial and market aspects: market and marketing aspects, aspects of the industrial environment, economic - social legal - environmental aspects; the values of key factors of product and service aspects: engineering and technology aspects, operational management aspects, human resource aspects; Values are key factors of the financial aspect. Each of the most important key factors is used as a component factor of the monthly and annual pharmacy company's targets that must be achieved.

Pharmacy management can increase revenue, sales, profit with the production of collaboration to selected factories / suppliers: herbal coffee, herbal tea, herbal honey, herbal juices, herbal milks, herbal cosmetics, spices concoction. Management can perform effective and efficient of promotion to increase market share and sales turnover,especially medicinal/herbal products. Advertising promotionthrough print media: newspapers, magazines, posters, banners, banners,baleho(billboards), back drop (background); electronic/digital media: mobile phone (smartphone), tablet, laptop computer, desktop computer, radio, television, videotron, video, google, youtube, electronic newspaper site, company website / company website , email / g-mail; social media : facebook, twitter, instagram, path, skype, line, whatsapp, tiktok; online sales (ecommerce, digital) through tokopedia, shoppee, blibli, bukalapak, lazadda.

\section{CONCLUSION}

Based on the feasibility analysis of the project / business plan of Ginsanjaya Pharmacy that has been carried out, conclusions can be drawn as follows:

Qualitative analysis of industry and market feasibility: worthy aspects of the market and marketing, worthy aspects of the industrial environment, worthy aspects of the economy - social - legal environment. Qualitative analysis of the 
feasibility of products and services: worthy of technical and technological aspects, worthy aspects of operational management, worthy aspects of human resources.

Quantitative analysis of financial aspects (financial): cash balance is always positive (>0); laba bersih always positip (>0); nilai BEP year 5: Rp 1,084,732,000, bep value of herbal medicine year 5: Rp 718,743,000; nilai NPV : Rp 543,461,000 $>0, \quad$ NPV value of herbal medicine : Rp $329,019,000>0$; nilai IRR : $27.412 \%>$ bank loan interest of $5.58 \%$, herbal medicine IRR value: $27.17 \%>5.58 \%$; nilai PI: $1.96>1$, HERBAL MEDICINE PI value: $2.04>1$; nilai PP: 3.32 years < project period of 5 years, herbal medicine PP value: 3.49 years $<5$ years.

So in conclusion the business plan / project of Ginsanjaya Pharmacy in Kranggan Permai, Jati Sampurna, Cibubur Raya / Kota Bekasi deserves to be realized, realized, and operated.

\section{Acknowledgement: None}

\section{Conflict of Interest: None}

\section{Source of Funding: None}

\section{REFERENCES}

1. Darman S, Zakaria FR, Muhandri Tj. 2015. Feasibility Study of The Establishment of Small Fish Feed Industry In Calingcing Cianjur. Journal of IKMManagement. 10 (1): 17 - 21.

2. Handjojo ES, Syarief R, Sugiyono. 2017. Papua Tea Business Feasibility Analysis (Vernonia amygdaline). Journal of IKM Management. 12 ( 2 ) : 145 - 150. http://journal.ipb.ac.id/index. php/jurnalmpi/

3. Kottler P. 1993. Marketing Management. Edition 7. Affif AZ. Translator. Pener-bit Faculty of Economics, University of Indonesia. Translation from Marketing Management.

4. Mahanani PIS. 2013. Report on The Working Practices of Pharmacist Profession At Mitrasana Pharmacy Jalan Boulevard Gading Timur Raya Kav 6 Kelapa Gading North Jakarta Period 1 April - 4 May 2013. Depok: University of Indonesia.
5. Mas'ud. 2009. Analysis of Customer Satisfaction Level of Pharmacy Service Kimia Farma Jakarta Using Serv Qual Model (Case Study In 3 Pharmacies). Pharmaceutical Science Magazine. Volume VI Number 2 August: 56 - 74. Jakarta : RSPAD Gatot Subroto.

6. Ministry of Health of the Republic of Indonesia. Decree of the Minister of Health of the Republic of Indonesia Number 1332 / Menkes / SK / X / 2002 Concerning the Provisions and Procedures for Granting Pharmacy Permits.

7. Ministry of Health of the Republic of Indonesia. Decree of the Minister of Health of the Republic of Indonesia Number 1027 / Menkes / SK / IX / 2004 Concerning Pharmacy Service Standards.

8. Ministry of Health of the Republic of Indonesia. Regulation of the Minister of Health Repu blik Indonesia Number $9 \mathrm{~T}$ ahun 2017 Concerning Pharmacies.

9. Narendra MP et al. 2017. Analysis of Customer Satisfaction Level of Service at Kimia Farma Pharmacy Gatot SubrotoBandung. Kartika: Scientific Journal of Pharmacy Volume 5 Number 1. Bandung: Universitas Jenderal AhmadYani. https://www.researchgate.net/publication/32 3680570.

10. Nurhakim SA, Suparno O, Nurrochmat DR. 2018. Development of XYZ Health Care Model and Strategy. Journal of Management and Business Applications. 4 (2): 251 - 260.

11. Oktaviani LR. 2018. Business Development Planning pharmacy K - 24 Jalan Amarta B-24 Wedomartani Sleman Yogyakarta. [Thesis]. Yogyakarta: Sanata Dharma University

12. Pkpa Kimia Farma Bandung Team. Pharmacy Feasibility Study https://www.academia.edu/6332797/Studi_ Kelayakan_Apotek.

13. PT Kimia Farma Tbk. 2021. Annual Report 2020, 2019, 2018, 2017. http://www.kimiafarma.co.id

14. Rianto, Sinaga BM, Kirbrandoko. 2018. Alternative Energy Development Investment Analysis to Lower Energy Costs at PT XYZ. Journal of Management and Business Applications. 4 (3): 409 - 419.

15. Satibi $M$ et al. Pharmacy Management. UGM Press. 
16. Sumarwan U et al. 2018. Marketing Strategy in Consumer Behavior Perspective. IPB publisher.

17. Sumarwan U et al. 2018. Business and Consumer Research Methods. Revised Edition. IPB publisher.

18. Sutojo S. 1993. Project Feasibility Study. Pustaka Binaman Pressindo \& LPPM.

19. Umar H. 2007. Business Feasibility Study. Edition 3. Gramedia Main Library Publisher.

20. Wahyudi A et al. 2017. Analysis of Pharmacy Business Feasibility in Rantepao Subdistrict of North Toraja Regency, South Sulawesi. E - Proceeding of Engineering. 4 (3): 4516 - 4524.

21. Witoko P, Syarief R, Raharja S. 2013. Feasibility and Business Development Strategy of Catfish Hatchery At CV Mika Distrindo. Journal of IKM Management. 8 (2): 115 - 122 .

22. Yasmine AN. 2015. Report on The Working Practices of Pharmacist Profession At Kimia Farma Pharmacy No. 42 Jalan Sultan Hasanudin No. 1 South Jakarta
Period September 2014. Depok: University of Indonesia.

23. Yulia PR, Baga LM, Djohar S. 2016. Consumer Satisfaction with Pharmacy Services and Level of Consumer Knowledge Regarding Applicable Pharmaceutical Service Standards (Case Study In Depok City). Journal of Management and Business Applications. 2 (3): 312 - 322 .

24. Zimmerer TW and Scarborough NM. 2008. Entrepreneurship and Small Business Management. Edition 5. Kwary, DA. and Fitrisari D. Translator. Publisher Salemba Four. Translation of Essentials of Entrepreneurship and Small Business Management.

How to cite this article: Gunawan Yohanda, Rizal Syarief, Yidha Herywan Asnawi. Feasibility analysis on the business plan of herb medicines at Ginsanjaya Pharmacy. International Journal of Research and Review. 2022; 9(1): 544-552. DOI: https://doi.org/10. 52403/ijrr.20220163 